\title{
The Impact of Computerization on Financial Reporting Practice: The Perspectives of International Non-Government Organizations
}

\author{
Williams Kwasi Peprah1, Isaac Owusu Amponsem² \\ ${ }^{1}$ Valley View University, Accra, Ghana \\ ${ }^{2}$ Adventist University of the Philippines, Silang, Cavite, Philippines \\ Email: Williams.peprah@vvu.edu.gh, ioamponsem@vvu.edu.gh
}

How to cite this paper: Peprah, W. K., \& Amponsem, I. O. (2021). The Impact of Computerization on Financial Reporting Practice: The Perspectives of International Non-Government Organizations. Open Journal of Accounting, 10, 105-110.

https://doi.org/10.4236/ojacct.2021.103009

Received: June 3, 2021

Accepted: July 13, 2021

Published: July 16, 2021

Copyright $\odot 2021$ by author(s) and Scientific Research Publishing Inc. This work is licensed under the Creative Commons Attribution International License (CC BY 4.0).

http://creativecommons.org/licenses/by/4.0/

\section{(c) (i) Open Access}

\begin{abstract}
It has become paramount for providers of funds for non-governmental organizations globally to require and request receivers of the funds to report financially. Financial reporting practices typically carry information and are shown in the income statement or statement of performance, statement of position, cash flow statement, funding sources, and statement of disclosure. Hence, this study investigated the impact of computerization on financial reporting practices of the six registered international non-governmental organizations in Ghana. The study used a correlational research design and applied bivariate analysis in SPSS version 23 on self-constructed questionnaires with Cronbach's Alpha of 0.78 for computerization and 0.82 for financial reporting practices. The results of the study showed that there is a highly significant positive relationship between computerization and financial reporting practices $(\mathrm{r}=0.851, \mathrm{p}=0.032)$. The study confirmed that most of the international non-governmental organizations in Ghana consistently receiving funding due to the proper computerization systems they have, which have aided the financial reporting practices that funders require. The study recommends that local non-governmental organizations computerize their accounting and financial reporting processes.
\end{abstract}

\section{Keywords}

Computerization, Financial Reporting Practices, International Non-Government Organizations 


\section{Introduction}

For suppliers of funds to non-profit and non-governmental organizations worldwide, it has become necessary to require and request financial reporting from the recipients of the funds. Financial reporting activities usually bear details that are shown in the performance statement, statement of position, statement of cash flow, sources of funding and statement of disclosure. The qualitative characteristics based on conceptualized financial reporting practices must be relevant, understandable, verifiable, timely and comparable, as reported by the International Financial Reporting Standard (IFRS) Foundation (2015). This is essentially what is expected at present by non-profit (NPO) or non-governmental organizations (NGOs).

The ongoing financial downturn in the global economy has imposed a burden on non-profit organizations due to limited resources, as aspirations and needs for non-profit organizations are growing. As a result, both within and outside the organization, multiple stakeholders expect non-profit organizations to illustrate and report on the efficient and meaningful economic use of funds. The scale of the non-profit sector is undeniably high in both developed and developing countries. It is estimated that there are approximately 870,000 organizations in the sector in the United Kingdom, with a total contribution of about $£ 116$ billion to the UK economy. At the end of 2011, there were over 161,000 registered charities with gross profits in excess of $£ 55.8$ billion in England, Scotland and Northern Ireland and Wales alone-potentially over 250,000 charities. There were about 1.1 million charities in the US at around the same time, with sales of over \$1.51 trillion in 2012, 85,000 registered charities in Canada, 60,000 in Australia and over 26,717 charities in New Zealand. It is estimated that there are between 1 and 2 million charities in developing economies such as India, China, Nigeria, Ghana and Pakistan (Crawford et al., 2018).

With the astronomical growth of the number of non-profit organizations (NPOs) in the world's developing economies and in sub-Saharan Africa, like Ghana, there has been a growing question about the practice of financial reporting. Accountability and Social Accounting for Social and Non-Profit Organizations (2014) argue that as their position grows, there is renewed interest in the world and an emphasis on non-profit organizations. This requires that financial transactions be adequately documented and published in order to meet the expectations of potential and current stakeholders and gain further funding. Various types of funders ask non-profit organizations for data on appraisal and performance evaluation. From the input they get, the stakeholders build their trust and faith in the structures (Henisz, 2017).

In order to ensure fair presentation and full disclosure of funds and activities, NGOs are required. Therefore, the practice of financial reporting should ensure uniformity, ease of interpretation and fulfillment of general accounting principles. Their compliance with related legal and contractual requirements must be determined and demonstrated (Bryce, 2017). In a Crawford et al. (2018) survey of six hundred and five (605) individuals engaged in financial reporting by 
non-profit organizations in at least one hundred and seventy-nine (179) countries, seventy-two percent (72 percent) indicated that they felt it would be useful to provide international standards for non-profit financial reporting.

The effect of computerization helped by the accounting system on financial reporting was examined by Murungi and Kayigamba (2015) at the Ministry of Local Government of Rwanda. According to the findings, 98 percent of respondents admit that the Ministry uses both cash-based and accrual-based computerized accounting systems, 38 percent of respondents accepted that transparency is improved by computerized accounting, while 31 percent of respondents say that timely financial statements are given by the system. The study advises that financial and accounting workers should be routinely and continuously trained by the licensed software dealers to remain well acquainted with the knowledge and expertise of the package for improved updates and versions of accounting packages.

Until recently, the dissertation by Hagan (2019) looked at the financial management of NGOs in Ghana; little information is available in the literature on the subject of financial reporting and computerization. This research has established a knowledge gap to resolve the problem of financial reporting as impacted by computerization from the perspective of international NGOs in Ghana.

In Ghana, a survey of the relationship between computerized accounting and financial reporting practices in rural banks was carried out by Opoku-Ware (2015). The researchers used 70 respondents at rural banks from three selected branches. The results of the study showed that a positive relationship existed between the art of financial reporting and computerized accounting.

A mixed-method analysis was carried out at Stanbic Bank, the Garden City Branch, by Amongin (2015). Fifteen respondents were used by the researchers. The study determined that the quality of the financial reports is highly affected by the computerized accounting system and that a lot of financial statements were produced. The results showed that the variables $(r=0.861, p>0.01)$ were significantly positive, which means that Stanbic Bank of Uganda is closely linked to computerized accounting and financial reporting. In order to run the enterprise, the computerized accounting system is of great importance but is also associated with its own drawbacks that impede the efficiency of the enterprise. It is advisable to use a computerized accounting system with a clear tradition.

The impact of the computerized accounting system on the financial report in the Ghana stock exchange banks was analyzed by Sekyere et al. (2017). The research findings showed that the financial reporting practices in Ghana are closely linked to the computerized framework of the listed banks. The study also found that most banks in Ghana operate a completely computerized financial reporting system in which the standard of financial reporting remained timely, reliable and precise because of their computerized accounting system. The study indicates that banks concentrate heavily on workers' education to satisfy the bank's tech knowledge needs. 
The relationship of computerized accounting systems with the financial reporting practices of small and medium enterprises has been explored in a study conducted in Sri Lanka by Shiraj (2015). The results of this analysis found a substantial effect on the quality of financial reporting in the computerized accounting system. The results showed strong positive relationships among the variables $(\mathrm{r}=0.741, \mathrm{p}>0.000)$, which means that SMEs in the South Eastern area of Sri Lanka have a computerized accounting and financial reporting system. The study shows that knowledge of the influence of computerized accounting systems in financial reporting is highly important and can be used by SMEs in order to establish successful strategies for future efficient delivery of financial reports.

The capital-labor complementarity theory states that the expense of workplace computerization by the individual business is greatly reduced (Blaug, 1997; Hamermesh, 1996). Due to the huge decrease in labor supply, the general income of capital investments has decreased dramatically because increased capital inputs do not cover the much bigger decrease in labour. In addition, capital is a complementary factor. In other words, the organization, by replacing a large number of workers with a single computer, is actually improving its future advantage. The conceptual framework of the study is shown in Figure 1 below.

\section{Methodology}

The study used a correlational research design and applied bivariate analysis in SPSS version 23 on self-constructed questionnaires with Cronbach's Alpha of 0.78 for computerization and 0.82 for financial reporting practices. Based on the data found on Schooleen Team website there are six international registered NGOs in Ghana. The total employees working at the accounts or finance departments were 57 and based on Yamane (1967) formula the sampled populations who were randomly sampled to answer the questionnaires were 50 . The researchers applied ethical consideration in protecting the respondents' confidentiality and anonmnity responses.

The research question and the null hypothesis for the study are as follows:

Is there a significant relationship between computerization and financial reporting practice?

$\mathrm{H}_{0}$ : There is no significant relationship between computerization and financial reporting practice.

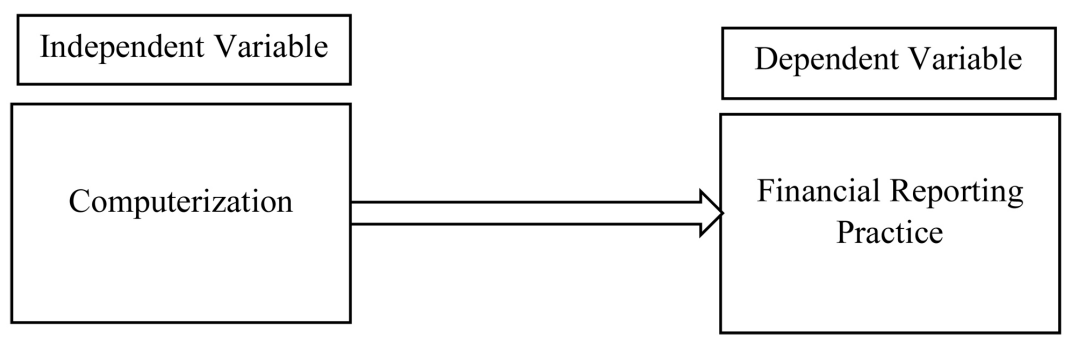

Figure 1. Research paradigm of computerization impact on financial reporting practice. 
Table 1. Correlate of computerization and financial reporting practice.

\begin{tabular}{ccc}
\hline & Financial Reporting Practice \\
\hline Computerization & Pearson Correlation & $0.851^{*}$ \\
& Sig. (2-tailed) & 0.032 \\
$\mathrm{~N}$ & 50 \\
\hline
\end{tabular}

${ }^{*}$ Correlation is significant at the 0.05 level (2-tailed).

\section{Results and Discussion}

The study findings in seeking the relationship between computerization and financial reporting practices among international non-government organizations in Ghana have released that there is a high positive significant relationship between computerization and financial reporting practice $(r=0.851, p=0.032)$ as shown in Table 1.

The result has shown that there is a positive influence of computerization on the financial reporting practice of international non-government organizations in Ghana. This high positive impact of computerization has aided the relevance, understandability, reliability, timeless and comparability of financial importance given by these international NGOs. The implication is seen in the constant funding that the international NGOs receive as compared to the local NGOs in Ghana who have not fully computerized their accounting systems in order to give quality reports to funders that are relevant, understandable, reliable, timely and comparable. The findings of this study are strongly supported by the studies of Opoku-Ware (2015), Sekyere, Amoateng and Frimpong (2017), Amongin (2015) and Shiraj (2015) as discussed in the literature. The study recommends that local non-governmental organizations computerize their accounting systems to ensure a positive financial reporting practice which donors now require. Also, accountants should learn the use of computerization and accounting software in order to achieve simple reporting. The study concludes that computerization has a highly significant positive influence on financial reporting practices. As the study is limited in the number of respondents used, it recommends further studies with larger sample size and in a different industry.

\section{Conflicts of Interest}

The authors declare no conflicts of interest regarding the publication of this paper.

\section{References}

Accountability and Social Accounting for Social and Non-Profit Organizations (2014). Advances in Public Interest Accounting. Bingley: Emerald Group Publishing.

Amongin, M. M. (2015). Computerised Accounting and Financial Reporting a Case Study of Stanbic Bank Garden City Branch. Master's Thesis, Makerere, Uganda: Makerere University. http://cees.mak.ac.ug/sites/default/files/publications/AMONGIN.pdf

Blaug, M. (1997). Economic Theory in Retrospect. Cambridge, UK: Cambridge University Press. https://doi.org/10.1017/CBO9780511805639 
Bryce, H. J. (2017). Financial and Strategic Management for Nonprofit Organizations (4th ed.). Berlin, Boston: De Gruyter. https://doi.org/10.1515/9781501505713

Crawford, L., Morgan, G. G., \& Cordery, C. J. (2018). Accountability and Not-for-Profit Organizations: Implications for Developing International Financial Reporting Standards. Financial Accountability and Management, 34, 181-205. https://doi.org/10.1111/faam.12146

Hagan, G. A. N. (2019). Financial Management of NGOs in Ghana: A Case Study of Central Aid. Doctoral Dissertation, Accra: University of Ghana.

Hamermesh, D. S. (1996). Labor Demand. Princeton, NJ: Princeton University Press.

Henisz, W. J. (2017). Corporate Diplomacy: Building Reputations and Relationships with External Stakeholders. London: Routledge. https://doi.org/10.4324/9781351287883

Murungi, S., \& Kayigamba, C. (2015). The Impact of Computerized Accounting System on Financial Reporting in the Ministry of Local Government of Rwanda. Journal of Emerging Trends in Economics and Management Sciences, 6, 261-265.

Opoku-Ware, E. (2015). Computerized Accounting System an Effective Means of Keeping Accounting Records in Ghanaian Banks: A Case Study of the Ga Rural. International Journal of Research in Business Studies and Management, 2, 111-141.

Sekyere, A. M., Amoateng, A. K., \& Frimpong, K. (2017). The Determinants of Computerized Accounting System on Accurate Financial Report in Listed Banks on the Ghana Stock Exchange. International Journal of Finance and Accounting, 6, 104-110.

Shiraj, M. M. (2015). The Impact of Using Computerized Accounting Systems (CAS) in Financial Reporting among Smes: Special Reference to the South Eastern Region, Sri Lanka. 5th International Symposium, 2, 50-53.

Yamane, T. (1967). Statistics: An Introductory Analysis. New York: Harper and Row. 